\title{
Respon Seleksi Berdasarkan Bobot Sapih dan Bobot Setahun pada Sapi Bali
}

\section{(Selection Response Based on Weaning Weights and Yearling Weights of Bali Cattle)}

\author{
Rumbesiano IY ${ }^{1}$, Supriyantono $\mathrm{A}^{2}$, Muin $\mathrm{MA}^{2}$ \\ ${ }^{1}$ Dinas Peternakan dan Kesehatan Hewan Prov. Papua Barat, Perkantoran Gubernur Papua Barat Arfai, Manokwari \\ ${ }^{2}$ Fakultas Peternakan Universitas Papua, Jl. Gn. Salju Manokwari \\ andoyo@yahoo.com
}

\begin{abstract}
Weaning weights and yearling weights are economical characteristics of production to be used as selection criteria in animal. The study aimed to evaluate selection response of weaning weight and yearling weights directly and to evaluate selection response of yearling weights indirectly through weaning weights. A total of 190 data from 23 sires and 133 dams were used to estimate the heritability of weaning weights. Data to estimate heritability of yearling weights were about 231 data from 20 sires and 101 dams. Data to estimate genetic correlation between weaning weights and yearling weights were about 194 data from 26 sires and 125 dams. The heritability was estimated by using a variance analysis of paternal half-sib correlation. The results showed that heritability of weaning weights and yearling weights were $0.63 \pm 0.291$ and $0.68 \pm 0.342$, respectively. The genetic correlation between weaning weights and yearling weights was 0.78 . The fewer proportions of animal that selection for, the higher selection response for weaning weights and yearling weights both directly and indirectly selection.
\end{abstract}

Key words: Selection response, weaning weights, yearling weights, Bali cattle

\begin{abstract}
ABSTRAK
Bobot sapih dan bobot setahun merupakan sifat produksi yang ekonomis untuk digunakan sebagai kriteria seleksi. Penelitian ini bertujuan untuk mengevaluasi respon seleksi bobot sapih dan bobot setahun secara langsung serta mengevaluasi respon seleksi bobot setahun secara tidak langsung melalui bobot sapih. Sebanyak 190 data keturunan yang berasal dari 23 pejantan dan 133 induk digunakan untuk menduga nilai heritabilitas bobot sapih, sedangkan untuk menduga nilai heritabilitas bobot setahun digunakan 231 data keturunan yang berasal dari 20 pejantan dan 101 induk. Nilai korelasi genetik antara bobot sapih dan bobot setahun diduga dengan menggunakan 194 pasangan data yang berasal dari 26 pejantan dan 125 induk. Nilai heritabilitas diduga dengan menggunakan analisis variansi data saudara tiri sebapak (paternal halfsib correlation). Hasil penelitian menunjukkan bahwa nilai heritabilitas bobot sapih dan bobot setahun berturut-turut sebesar 0,63 $\pm 0,291$ dan 0,68 $\pm 0,342$. Nilai korelasi genetik antara bobot sapih dan bobot setahun sebesar 0,78. Semakin sedikit proporsi populasi yang dipertahankan maka semakin tinggi respon seleksi pada bobot sapih maupun bobot setahun baik secara langsung maupun tidak langsung.
\end{abstract}

Kata kunci: Respon seleksi, bobot sapih, bobot setahun, sapi Bali 


\section{PENDAHULUAN}

Sapi Bali merupakan salah satu jenis sapi lokal yang sangat potensial untuk dikembangkan. Hal ini disebabkan karena sapi Bali memiliki daya adaptasi yang sangat tinggi terhadap lingkungan yang kurang baik seperti mampu memanfaatkan pakan dengan kualitas rendah, mempunyai fertilitas yang sangat baik, dan persentase karkas yang tinggi (Hardjosubroto 1994).

Potensi-potensi tersebut memberikan minat untuk melestarikan dan mengembangkan ternak sapi Bali. Upaya-upaya yang telah dilakukan antara lain dengan meningkatkan produktivitas melalui perbaikan mutu pakan dan program pemuliaan melalui seleksi dan persilangan. Kemajuan perbaikan mutu genetik ternak melalui aplikasi teknik pemuliaan khususnya seleksi sangat ditentukan oleh kekuatan pewarisan dan mutu genetik dari sifatsifat yang diperbaiki (Kihe 1992). Kekuatan pewarisan suatu sifat dapat dicirikan sebagai keragaman genetik khususnya gen aditif sifat tersebut pada suatu populasi tertentu, karena gen yang sifatnya aditif inilah yang dapat diwariskan pada generasi berikutnya (Warwick et al. 1990; Hardjosubroto 1994).

Performan seekor ternak merupakan hasil dari pengaruh faktor keturunan dan pengaruh kumulatif dari faktor lingkungan yang dialami oleh ternak bersangkutan (Hardjosubroto 1994). Bobot sapih pada sapi potong merupakan salah satu sifat yang mempunyai arti ekonomi yang sangat penting karena merupakan sifat yang lebih awal dapat diamati atau diukur untuk digunakan sebagai kriteria seleksi dan dapat berpengaruh positif terhadap sifat-sifat pertumbuhan selanjutnya (Taylor 1984). Bobot sapih mempunyai nilai heritabilitas yang tinggi dan korelasi genetik yang tinggi pula dengan bobot setahun (Dickerson et al. 1974). Nilai heritabilitas bobot sapih potong berkisar 0,30 sampai 0,45 dan korelasi genetik antara bobot sapih dan bobot setahun adalah 0,80 (Kurnianto 2009). Nilai heritabilitas yang tinggi menunjukkan bahwa korelasi ragam fenotipe dengan ragam genetik adalah tinggi sehingga seleksi berdasarkan fenotipe bobot sapih individu akan cukup efektif.

Bobot setahun adalah sifat produksi yang dapat dipakai sebagai kriteria seleksi terhadap kemampuan pertumbuhan hewan muda. Bila pedet tersebut memiliki bobot setahun yang tinggi, hal ini menggambarkan bahwa hewan itu mampu tumbuh cepat dan efisien dalam pencapaian bobot potong. Sedangkan pada pedet betina bila didukung oleh sifat produksi yang baik, maka hewan betina tersebut sangat potensial digunakan sebagai calon induk (Talib et al. 2002). Seleksi secara tidak langsung pada sifat bobot setahun lebih efisien dalam hal waktu dan lebih ekonomis. Sesuai dengan pendapat Falconer \& Mackay (1997), bahwa dengan memanfaatkan korelasi genetik maka dapat dilakukan seleksi lebih dini sehingga dapat menghemat biaya dan waktu.

\section{MATERI DAN METODE}

\section{Data}

Data bobot sapih dan bobot setahun berasal dari Balai Pembibitan Ternak Unggul Sapi Bali di Pulukan selama10 tahun terakhir. Sebanyak 190 data bobot sapih yang berasal dari 23 pejantan dan 133 induk dengan jumlah anak tiap induk berkisar 1-3 ekor dan jumlah anak tiap pejantan berkisar antara 2-20 ekor, digunakan untuk menganalisis nilai heritabilitas. Sementara untuk data bobot setahun sebanyak 135 data yang berasal dari 20 pejantan dan 101 induk dengan jumlah anak tiap induk berkisar antara 1-4 dan jumlah anak tiap pejantan berkisar antara 2-16 ekor. Untuk menganalisis korelasi genetik 
antara bobot sapih dan bobot setahun, digunakan 194 pasangan data yang berasal dari 26 pejantan dengan jumlah anak berkisar dari 2-12 ekor dan 125 induk dengan jumlah anak berkisar antara 1-5 ekor.

Hubungan kekeluargaan antar anak yang diambil adalah hubungan saudara tiri sebapak. Sumber-sumber keragaman non genetik yang sangat mungkin terjadi pada populasi ini adalah jenis kelamin dan musim.

\section{Manajemen sapi Bali}

BPTU Sapi Bali merupakan pengembangan dari Proyek Pengembangan Pembibitan (P3) Sapi Bali dengan tujuan utama adalah peningkatan mutu genetik sapi Bali. Pada pembibitan ini, pejantan-pejantan sapi Bali diseleksi pada umur 1 tahun dari village breeding center (Tabanan dan Karang Asem). Pejantan tersebut dikumpulkan di Pulukan untuk dilakukan uji performa bersama-sama pejantan lain yang berasal dari Pulukan itu sendiri. Data silsilah dan informasi lain terkait pertumbuhan sapi Bali dicatat dengan baik. Periode perkawinan sapi Bali di kelompok ini terjadi pada bulan Juli hingga Desember dengan menggunakan penjantan alami dan inseminasi buatan. Musim beranak terjadi pada bulan April hingga Oktober, kemudian pedet dipelihara bersama-sama dengan induk hingga masa sapih. Dalam waktu 12 jam sejak kelahiran pedet, pedet ditimbang dan diberikan tanda di telinga (ear tag). Identitas pedet baru dan tetuanya, tanggal lahir, jenis kelamin dan bobot lahir dicatat dengan baik di data base. Lamanya periode menyusui tidak sama untuk semua pedet. Selama periode menyusui, pedet diberi pakan tambahan berupa rumput raja dan konsentrat pabrik. Sebagian besar pedet disapih pada bulan Mei. Setelah disapih, pedet ditempatkan terpisah dari induknya. Pada umur 18 bulan, sapi diberi perlakuan yang sama pada uji performa.

\section{Analisis data}

Data yang diperoleh dikoreksi atau dilakukan penyesuaian untuk mengeliminir pengaruh ragam lingkungan (non genetik) seperti jenis kelamin, musim, umur sapih dan umur induk. Hasil analisis data terhadap bobot sapih dan bobot setahun menggunakan uji $\mathrm{T}$ untuk faktor non genetik jenis kelamin dan musim menunjukkan bahwa terdapat perbedaan nyata $(\mathrm{P}<0,05)$ sehingga data tersebut perlu dilakukan koreksi terhadap jenis kelamin yang diarahkan ke jenis kelamin jantan dan musim yang diarahkan ke musim penghujan. Sedangkan untuk umur sapih dan umur induk menggunakan tabel yang disediakan oleh Hardjosoebroto (1994).

Estimasi heritabilitas untuk semua sifat dilakukan analisis variansi dengan menggunakan data saudara tiri sebapak (paternal halfsib correlation). Analisis yang digunakan adalah Rancangan Acak Lengkap pola searah dengan model $Y_{i k}=\mu+a_{i}+e_{i k}$; dimana $\mathrm{Y}_{\mathrm{ik}}=$ pengamatan pada individu ke-k pada pejantan ke-i; $\mu=$ rataan populasi; $\mathrm{a}_{\mathrm{i}}=$ pengaruhg pejantan ke-i; $\mathrm{e}_{\mathrm{ik}}=$ penyimpangan efek lingkungan dan genetik yang tidak terkomntrol dari setiap individu. Estimasi korelasi genetik dilakukan dengan analisis covarians. Perhitungan respon seleksi langsung per generasi dan seleksi tidak langsung membutuhkan parameter heritabilitas, simpangan baku, intensitas seleksi dan korelasi genetik. 


\section{HASIL DAN PEMBAHASAN}

\section{Pengaruh faktor non genetik terhadap bobot sapih dan bobot setahun}

Hasil uji statistik menunjukkan bahwa faktor non genetik, sex dan musim, berpengaruh nyata $(\mathrm{P}<0,05)$ terhadap bobot sapih dan bobot setahun. Pada musim panas yang terjadi pada bulan April hingga bulan September bobot sapih dan bobot setahun nyata lebih rendah dibandingkan pada musim penghujan. Fuquay (1981) produktivitas ternak dipengaruhi oleh stress panas. Pada suhu lingkungan yang tinggi, ternak berusaha menurunkan produksi panas dan menyeimbangkan suhu tubuh dengan menurunkan konsumsi pakan (Leng 1990; Dahlanuddin \& Thwaites 1993; Rianto et al. 2001). Kondisi ini terjadi jika ternak tidak dapat melepaskan panas tubuh melalui konduksi, konveksi, evaporasi dan radiasi. Penurunan suhu melalui evaporasi terjadi saat suhu udara di sekitar ternak lebih rendah daripada suhu permukaan kulit ternak (Fuquay 1981). Selama stress panas, produksi ternak seperti pertambahan bobot badan harian secara umum berada pada keadaan stagnan (McGuire et al. 1989; Knapp \& Grummer 1991). Rendahnya bobot sapih dan bobot setahun pada musim panas antara lain disebabkan kurangnya ketersediaan hijauan baik kualitas maupun kuantitas. Assan \& Makuza (2005) bahwa perbedaan performa antar tahun merefleksikan variasi lingkungan, terutama perbedaan curah hujan dan ketersediaan hijauan secara kualitas dan kuantitas. Perbedaan antar tahun merupakan fenomena yang wajar dan secara normal disebabkan oleh fluktuasi kondisi lingkungan yang sulit dikontrol (Assan \& Makuza 2005). Tahun kelahiran pedet berpengaruh nyata terhadap bobot lahir (Magnus \& Brink 1971). Perbedaan besar dalam curah hujan mengakibatkan perbedaan yang nyata pada tersedianya kualitas dan kuantitas hijauan (Khombe 1985).

Bobot sapih dan bobot setahun sapi Bali jantan pada penelitian ini nyata lebih tinggi daripada sapi Bali betina, hal ini disebabkan oleh adanya aktivitas hormon kelamin yang dilepaskan oleh gonad. Roger et al. (1988), androgen dan estrogen selain penting dalam berbagai aspek pertumbuhan, perkembangan, dan membedakan morfologi alat kelamin jantan dan betina (karakter kelamin primer), kemudian perkembangan dan tingkah laku seksual dan reproduksi (karakter kelamin sekunder), juga dapat merangsang pertumbuhan jaringan tubuh. Lebih lanjut, diterangkan bahwa hormon androgen lebih berperan menunjang pertumbuhan secara umum, khususnya dalam pembentukan protein, jika dibandingkan dengan hormon estrogen pada kebanyakan hewan bertulang belakang. Nalbandov (1980), hormon estrogen pada betina dapat membatasi pertumbuhan tulang pipa dalam tubuh. Haresign (1983) menyatakan bahwa proses pembentukan tulang pada fase prenatal sudah berlangsung pada hari ke-50 masa kebuntingan. Dengan demikian, hormon estrogen yang dihasilkan oleh foetus betina akan menghambat pertumbuhan tulang pipa sejak hormon estrogen tersebut berfungsi. Dengan terhambatnya pertumbuhan tulang pipa, maka tempat melekatnya daging akan berkurang, sehingga laju pertumbuhan otot terbatas. Atas dasar pernyataan tersebut, maka jelas bahwa tendensi pertambahan bobot badan per hari untuk jantan lebih besar jika dibandingkan dengan betina.

\section{Heritabilitas bobot sapih dan bobot setahun}

Hasil analisis ragam dan pemisahan komponen ragam diperoleh nilai estimasi heritabilitas $\left(h^{2}\right)$ untuk bobot sapih dan bobot setahun pada populasi sapi Bali penelitian

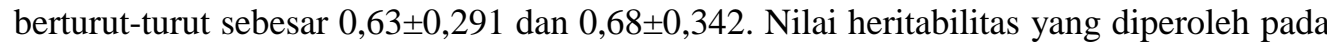
penelitian ini lebih tinggi bila dibandingkan dengan hasil penelitian Sukmasari et al. 
(2002) di P3 Bali dengan menggunakan perangkat lunak variance component estimation yang memperoleh nilai heritabilitas sebesar 0,23 $\pm 0,02$ untuk bobot sapih; 0,38 $\pm 0,02$ untuk bobot setahun. Davis \& Simmen (2006) perbedaan pada nilai heritabilitas dapat disebabkan oleh pengaruh contoh. Selanjutnya, perbedaan pada nilai heritabilitas juga dapat disebabkan oleh perbedaan populasi misalnya kondisi lingkungan yang berbeda dapat menurunkan besaran nilai heritabilitas dan frekuensi gen (MacNeil et al. 2000; Tribudi et al. 2019). Kealey et al. (2006) menyatakan bahwa perbedaan dalam metode analisis berpengaruh terhadap keakuratan heritabilitas. Nilai heritabilitas tergantung pada besarnya komponen-komponen ragam yang menyusunnya, apabila ada perubahan komponen ragam maka akan mempengaruhi nilai heritabilitas (Lasley 1978) karena heritabilitas adalah bagian dari keragaman total dari suatu sifat yang disebabkan oleh pengaruh genetik (Warwick et al. 1990). Tingginya nilai heritabilitas menunjukkan bahwa perbedaan penampilan pada karakter tersebut lebih dipengaruhi oleh genetik dan sedikit oleh lingkungan. Falconer \& Mackay (1997) menyatakan bahwa seleksi berdasarkan karakter yang tidak dipengaruhi oleh lingkungan dengan nilai heritabilitas besar akan memberikan nilai harapan kemajuan seleksi yang besar.

\section{Korelasi genetik antara bobot sapih dan bobot setahun}

Hasil analisis korelasi genetik menunjukkan bahwa karakter bobot sapih sapi Bali $(0,78)$ berkorelasi genetik positif dengan bobot setahun. Hal ini berarti bahwa perbaikan bobot sapih karena seleski akan memperbaiki bobot setahun sapi Bali. Meningkatnya derajat korelasi genetik mengekspresikan bahwa kedua karakter dipengaruhi oleh gen-gen yang sama sehingga memiliki hubungan yang erat, oleh karena itu seleksi terhadap satu sifat akan meningkatkan sifat yang lain (Abdullah \& Olutogun 2006) sehingga kedua sifat ini dapat dipertimbangkan sebagai sifat yang sama dalam program seleksi.

Hasil ini sejalan dengan penelitian Kurnianto (2009) yang menyatakan bahwa bobot sapih berkorelasi genetik positif $(0,80)$ dengan bobot umur setahun sapi Bali. Lebih lanjut Sukmasari et al. (2002) dan Gunawan et al. (2012) melaporkan nilai korelasi genetik antara bobot sapih dan bobot setahun pada sapi Bali adalah 0,70 dan 0,72. Eler et al. (1995) melaporkan nilai korelasi genetik bobot sapih dan bobot setahun pada sapi Nelore adalah 0,16. Namun demikian, dibandingkan dengan penelitian lain (Meyer 1994) yang melaporkan bahwa korelasi genetik bobot sapih dan bobot setahun pada sapi Angus dan persilangan Zebu yaitu 0,95 dan 0,79; Pico et al. (2004) melaporkan nilai korelasi genetik sebesar 0,88 pada sapi Brahman di Afrika Selatan, maka korelasi genetik pada penelitian ini lebih rendah.

\section{Respon seleksi langsung dan tidak langsung}

Guna mengukur kemajuan genetik, maka dihitung respons seleksi yang diperoleh setelah dilakukan seleksi (Tabel 1 dan Tabel 2). Intensitas seleksi yang digunakan pada tabel 1 menunjukan bahwa respons seleksi bobot sapih dan bobot setahun pada generasi yang akan datang dengan proporsi seleksi $5 \%$ adalah sebesar 10,07 kg dan bobot setahun sebesar $24,55 \mathrm{~kg}$ diatas rata-rata populasi akibat dilakukan seleksi pada generasi sekarang. Semakin tinggi porporsi ternak diseleski, maka semakin menurun intensitas seleksinya, yang pada akhirnya menurunkan respon seleksi pada generasi berikutnya (Hardjosubroto 1994). Seleksi bobot sapih dan bobot setahun sapi Bali secara langsung diharapkan memberikan respon seleksi yang maksimal, karena bobot sapih dan bobot setahun sapi Bali memiliki nilai heritabilitas yang cukup tinggi. Selanjutnya Warwick et al. (1990), menyatakan bahwa pada 
waktu melakukan seleksi, maka ternak yang mempunyai kinerja lebih tinggi dari kinerja yang telah ditentukan akan dipilih, sedangkan yang lebih rendah akan disingkirkan.

Tabel 1. Nilai respon seleksi langsung dengan intesitas seleksi berbeda

\begin{tabular}{lccc}
\hline \hline Karakter & $\begin{array}{c}\text { Proporsi seleksi } \\
(\%)\end{array}$ & Intesitas seleksi & $\begin{array}{c}\text { Respon seleksi } \\
\text { (kg/Generasi) }\end{array}$ \\
\hline \multirow{3}{*}{ Bobot sapih } & 5 & 2.063 & 10,07 \\
& 10 & 1.755 & 8,57 \\
Bobot setahun & 15 & 1.554 & 7,59 \\
& 5 & 2.063 & 24,55 \\
& 10 & 1.755 & 20,88 \\
\hline
\end{tabular}

Nilai intensitas seleksi (i) diperoleh dari Falconer \& Mackay (1997)

Pada Tabel 2, respon seleski bobot setahun melalui bobot sapih yang tertinggi adalah dengan menggunakan proporsi seleksi $5 \%$ sebesar $18,70 \mathrm{~kg}$. Hasil dari penelitian menunjukan bahwa kunci keberhasilan metode seleksi bobot setahun melalui bobot sapih adalah nilai heritabilitas dan korelasi genetik harus tinggi. Pada kenyataannya prosedur metode seleksi tidak langsung memiliki prosedur yang baku yaitu dengan memanfaatkan variasi yang maksimal antara individu yang diseleksi dengan rata-rata populasi, dan memaksimalkan heritabilitas dengan menurunkan ragam lingkungan sebaik mungkin. Suatu karakter dapat digunakan sebagai kriteria seleksi jika memiliki nilai heritabilitas yang tinggi dan berperan dalam peningkatan bobot sapi Bali. Falconer \& Mackay (1997) menyatakan bahwa seleksi yang dilakukan pada karakter pertama untuk meningkatkan karakter kedua disebut dengan seleksi tidak langsung atau respon seleksi berkorelasi.

Tabel 2. Nilai respon seleksi tidak langsung pada karakter bobot setahun dengan intesitas seleksi berbeda

\begin{tabular}{lcc}
\hline \hline Proporsi seleksi (\%) & Intesitas seleksi & $\begin{array}{c}\text { Respon seleksi } \\
\text { (kg/generasi) }\end{array}$ \\
\hline 5 & 2.063 & 18,70 \\
10 & 1.755 & 15,91 \\
15 & 1.554 & 14,09 \\
\hline
\end{tabular}

\section{KESIMPULAN}

Dari hasil penelitian dapat diambil beberapa kesimpulan sebagai berikut:

1. Nilai heritabilitas bobot sapih dan bobot setahun dengan analisis variansi menggunakan data saudara tiri sebapak (paternal halfsib correlation) berturut-turut

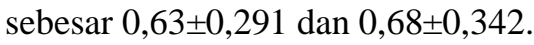

2. Karakter bobot sapih berkorelasi positif dengan bobot setahun karena memiliki nilai korelasi genetik sebesar 0,78. 
3. Semakin sedikit porporsi populasi yang diseleksi maka semakin tinggi respon seleksi pada bobot sapih maupun bobot setahun, baik secara langsung maupun tidak langsung.

\section{DAFTAR PUSTAKA}

Abdullah AR, Olutogun O. 2006. Estimates of genetic and phenotypic parameters for preweaning growth traits of N'Dama (Bos taurus) calves in the humid tropics of Nigeria [Internet]. Livest Res Rur Develop. Available from: http://www.cipav.org.co/lrrd/lrrd18/8/ab du18120.htm

Assan N, Makuza SM. 2005. The effect of non-genetic factors on birth weight and weaning weight in three sheep breeds of Zimbabwe. Asian-Aust J Anim Sci. 2:151-157.

Dahlanuddin, Thwaites CJ. 1993. Feed-water intake relations in goats at high ambient temperatures. J Anim Physiol A Anim Nutr. 69:169-174.

Davis ME, Simmen RCM. 2006. Genetic parameter estimates for serum insulin-like growth factor I concentrations and body weight and weight gain in Angus beef cattle divergently selected for serum insulin-like growth factor I concentrations. J Anim Sci. 84:22992308.

Dickerson GE, Kunzi N, Cundiff LV, Koch RM, Arthaud VH, Gregory KE. 1974. Selection criterion for efficient beef production. J Anim Sci. 39:659-673.

Eler JP, Van Vleck LD, Ferraz JBS, Lobo RB. 1995. Estimation of variance due to direct and maternal effects for growth traits of Nelore cattle. J Anim Sci. 73:3253-3258.

Falconer DS, Mackay TFC. 1997. Introduction to quantitative genetics. 4th ed. Harlow (UK): Addison Wesley Longman Limited, Edinburgh Gate.

Fuquay JW. 1981. Heat stress as it affects animal production. J Anim Sci. 52:164-174.

Gunawana AR, Sarib, Jakaria. 2012. Estimates of genetic and phenotypic trends of growth traits in Bali cattle. Media Peternakan. 2:85-90.

Hardjosubroto W. 1994. Aplikasi pemuliabiakan ternak di lapangan. Jakarta (Indonesia): PT Gramedia Wiadiasarana Indonesia.

Haresign W. 1983. Sheep production. London (UK): First Published Butterths.

Hasler MJ, Nalbandov AV. 1980. Ovulation, ovum maturation and changes in plasma and adrenal progesterone concentrations in the musk shrew (Suncus murinus). Biol Reprod. 22:377-381.

Kealey CG, MacNeil MD, Tess MW, Geary TW, Bellows RA. 2006. Genetic parameter estimates for scrotal circumferences and semen characteristics of line 1 Hereford bulls. J Anim Sci. 84:283-290.

Khombe CT. 1985. Environmental Factors affecting the growth and viability of crossbred sheep and goats on range in Zimbabwe. In: Small Ruminants in African Agriculture.

Kihe JN. 1992 Analisis potensi genetik sifat-sifat pertumbuhan ternak kambing PE saat lahir sampai sapih di Unit Pembibitan Ternak dan Hijauan Makanan Ternak (UPT HMT) Batu, Malang (Tesis). [Yogyakarta (Indonesia)]: Pascasarjana Universitas Gajah Mada.

Knapp DM, Grummer RR. 1991. Response of lactating dairy cows to fat supplementation during heat stress. J Dairy Sci. 74:2573-2579.

Kurnianto E. 2009. Pemuliaan ternak. Yogyakarta (Indonesia): Graha Ilmu. 
Lasley JE. 1978. Genetics of livestock improvement. 3rd ed. New Jersey (USA): PrenticeHall, Inc. Englewood Cliffs.

Leng RA. 1990. Factors affecting the utilization of "poor quality" forage by ruminants particularly under tropical conditions. Nutr Res Rev. 3:277-303.

MacNeil MD, Urick JJ, Decoudu G. 2000 Characteristics of line 1 Hereford female resulting from selection by independent culling levels for below-average birth weight and high yearling weight or by mass selection for high yearling weight. J Anim Sci. 84:22922298.

Magnus WL, Brink JS. 1971. Relationship between direct and maternal effect on growth in Herefords. I. Environmental factors during pre-weaning growth. J Anim Sci. 32:17-25.

Mc Guire MA, Beede DK, Delorenzo MA, Wilcox CJ, Huntington GB, Reynolds CK, Collier, RJ. 1989. Effect of thermal stress and level of feed intake on portal plasma flow and net fluxes of metabolites in lactating Holstein cows. J Anim Sci. 67:1050-1060.

Meyer K. 1994. Estimates of direct and maternal correlations among growth traits in Australian beef cattle. Livest Prod Sci. 38:91-105.

Pico BA, Nesser FWC, van Wyk JB. 2004. Genetic parameters for growth traits in South African Brahman cattle. South Afr J Anim Sci. 34:44-46.

Rianto E, Thwaites CJ, Nolan, JV. 2001. The effect of high ambient temperatures and urea supplementation on feed digestibility and microbial protein production in lambs. J Trop Anim Dev. Special Edition: October 2001.

Roger P, Taton M, van Sande J, Dumont JE. 1988. Mitogenic effect of thyrotropin and adenosine 3' 5'-monophosphate in differentiated normal human thyroid cells in vitro. J Clin Endocrinol Metab. 66:1158-1165.

Sukmasari AH, Noor RR, Martojo H, Talib C. 2002. The estimation of breeding values and genetics trends of body weight in Bali cattle improvement project. Hayati. 9:109-113.

Taylor RE. 1984. Beef production and the beef industry. Minnesota (USA): Burgess Publishing Company.

Talib CK, Entwistle K, Siregar A, Budiarti-Turner S, Lindsay D. 2002. Survey of population and production dynamics of Bali cattle and existing breeding programs in Indonesia. Working Papers: Bali Cattle Workshop.

Tribudi YA, Nurgiartiningsih VMA, Prihandini PW. 2019. Pendugaan nilai heritabilitas sifat pertumbuhan pada sapi Madura. Jurnal Ilmu-Ilmu Peternakan. 29:152-157.

Warwick EJ, Astuti JM, Hardjosubroto W. 1990. Pemuliaan ternak. Yogyakarta (Indonesia): Gadjah Mada University Press. 